\title{
Integrating News Media into History Classes to Teach both Content and Civic Literacy Skills
}

\author{
Dr. Eric Martone \\ School of Education \\ Mercy College \\ 555 Broadway \\ Dobbs Ferry, New York 10522, United States
}

\begin{abstract}
This article provides a practical guide for how secondary education social studies teachers can take an integrative approach to the use of current media articles to develop their students' civic literacy skills (reading for information as well as interdisciplinary writing) while enriching the teaching of content in their current history classes.
\end{abstract}

Keywords: social studies, history education, literacy, media, civics

In many social studies classrooms across the United States, a substantial amount of instructional time is allotted providing additional support for state-mandated standardized testing of reading and writing. Such a reallocation of instructional time for teaching literacy may reduce the time used for teaching for social studies-specific content and skills, thereby resulting in a deficit in students' social studies education. However, high-stakes testing's focus on literacy has presented social studies teachers with the opportunity to identify methods for merging social studies content with activities that can strengthen students' literacy skills, and vice versa. Such strategies engage students to increase their comprehension skills by determining, applying, and synthesizing meaning. They also enable students to organize and articulate what they have learned.

One technique to accomplish this goal involves literacy activities that use current news media related to the content covered in U.S. and global history classes. This article provides a practical guide for middle and high school social studies teachers to use to this end. Teachers will ultimately be able to develop at least one activity for every unit covered in the course. The selected news article should be accompanied by questions designed to help students develop their reading for information skills, and skills necessary to organize information from the article to write a critical writing piece or essay. Social studies teachers can therefore take an integrative approach to the use of current news articles to develop their students' civic literacy skills (reading for information as well as interdisciplinary writing), while enriching the teaching of content in their U.S. and global history classes.

Teaching students to use news and information media is an important aspect of civic education, especially in the contemporary climate. In a global society, citizens need a set of literacies that will enable them to think critically, communicate effectively, and ultimately act conscientiously. The dynamic nature of the online information landscape, the growing divisiveness in American politics, and increasing distrust in democratic institutions have all contributed to an increase in the circulation of misinformation. Such elements have made the ability to assess the credibility of news and information more challenging for both adults and adolescents. Consequently, if the contemporary American education system is to foster the development of students' cognitive learning skills to better prepare them for the future, a high-quality civic literacy education is essential. Information literacy is required in several state standards, and it is also frequently defined as an important " 21 st-century skill"(Partnership for 21 st Century Skills, 2019). According to a study conducted among social studies teachers in Western New York State, all respondents surveyed included among their primary goals the need to develop "critical-thinking skills," while 64\% identified the importance of developing "content knowledge"(Serure, 2018). Developing the activities suggested in this article will allow students to gain familiarity with this type of writing while simultaneously learning social studies content.

The teaching approach outlined in this article was developed from practical experience gained while serving as a social studies teacher in an urban district in Connecticut with many ELLs. With a focus on teaching literacy and practical skills that would help my students become informed decision makers, I sought to locate a news article for every unit covered in my U.S. and global history courses. The articles were accompanied by questions designed to help students develop their reading for information skills and/or skills necessary to organize information from the article to write an essay, arguing a position and using evidence from the article. These activities could then be used as part of, or the starting/guiding point for, a unit. At that time in Connecticut, sophomore students took reading and writing tests as part of the Connecticut Academic Performance Test (CAPT), administered by the Connecticut State Board of Education, as a standardized means for monitoring student progress. One of the two tests for reading, 
Reading for Information, required students to read various news articles and respond to open-ended and multiplechoice questions.

The two writing tests, Interdisciplinary Writing I and Interdisciplinary Writing II, required students to read two news articles on a divisive issue and take a clear stance on it, writing a persuasive letter that used evidence from the two sources. Social studies teachers were assigned primary responsibility for the Interdisciplinary Writing tests and secondary responsibility for the Reading for Information test (Higgins, 2012; St. Onge, Scalia, \& Vega, 2008). As a result, the social studies curriculum included an emphasis on teaching skills rather than just content. Therefore, there was a concern not with what students should know, but with what they can do. With the prevalence of the Common Core, such a focus has only become more relevant and widespread across the U.S.(Schmoker\&Jago, 2013).

\section{Making the Literacy-Social Studies Connection for Teaching Civic Literacy}

Studying language is the foundation of all learning, for students cannot construct any meaning or understanding of the world without using language. In other words, many of the language arts-such as reading, writing, speaking, and listening - cannot be separated from the content areas (such as social studies) because these are the skills through which students learn the content of other disciplines. In learning the content of other disciplines, students primarily learn each discipline's academic language. This type of language is often used in textbooks, classrooms, and assessments (Marlatt, 2018; Spires, Kerkhoff, Graham, Thompson, \& Lee, 2018; Sweeney \& Townsend, 2018).

Since 2010, with the rise of the Common Core (as a general set of skills-based standards) and the push to make students career- and college-ready, social studies teachers have increasingly been encouraged to teach social studies through reading and writing, and vice versa. The social studies curriculum has always included components that overlap with teaching literacy skills (Monte-Sano, 2011). Consequently, adapting social studies to the common core required a reconceptualization of the purpose of social studies and what social studies teachers do, rather than wholesale curriculum redevelopment (Stoll, 2018; Kenna \& Russell, 2014; Johnson \& Janisch, 1998; Waters \& Watson, 2016). As content areas not connected to high-stakes testing are often marginalized in the broader school curriculum, the Common Core standards' inclusion of an emphasis on informational texts to teach reading provided an opportunity to re-position and re-vitalize social studies education (Sharp \& Purdum, 2019). However, since social studies teachers are often expected to alter their instructional practices as a direct result of the implementation of the Common Core standards, this can additionally reduce the amount of instructional time that can be devoted to teaching content and enrichment activities (Kenna \& Russell, 2015).

Nevertheless, in a participatory democracy, we expect citizens to make informed decisions. In order for students to become informed decision makers, they need to develop the literacy skills necessary to be able to research and read critically. The NYS Grades 9-12 Social Studies Framework consequently includes literacy standards based on the Common Core that focus on determining the central ideas of a written source, analyzing how a text uses structure to emphasize key points or advance an explanation, comparing points of view in their treatment of the same or similar topics, identifying bias, assessing the extent to which the reasoning and evidence in a text support its claims, and developing one's own position while citing specific textual evidence to support it (New York State Education Department and the State University of New York, 2015).

News/media articles (particularly online news channels and sources) are among the main sources from which students obtain information. A strong familiarity with this type of writing and the ability to read it critically is a key component of civic literacy in contemporary society. Civic literacy thus requires students to read news and other media articles. Social studies teachers are well-positioned to help teach these skills, and headway has already been made in this area. For example, promising results have been obtained in terms of teaching students about the role of social media, and showing them how to identify factually inaccurate civic information. Research has also shed light on the factors influencing the ability to discern the accuracy of such information (Mihailidis, 2018; Middaugh,2019; Shulsky, Baker, Chvala, \& Willis, 2017; Hodgin \& Kahne, 2018; Paquette \& Kaufman,2008). However, such strategies have fallen short of integrating the teaching of civic literacy skills with social studies content, particularly while teaching U.S. and global history.

Moreover, school populations across the U.S. have experienced a growth in English language learners (ELLs). Educators have developed various instructional models for teaching ELLs that unite the dual goals of language learning and content learning (Haager \& Osipova, 2017).An approach commonly referred to as "sheltered instruction" is one example of such an approach. Therefore, for social teachers with a large ELL student population, civic literacy activities that combine the learning of civic literacy skills with social studies content are a means by which to further these types of instructional models within a general classroom. 
Many of the skills learned through primary source documents can also be learned as part of the civic literacy activities using news articles described in more detail later in this article-such as reading for information, identifying points of view/bias/etc., identifying competing arguments and their supporting evidence, and developing a position/stand on an issue and supporting it logically with text-based evidence.

Social studies teachers often encounter unique challenges when implementing primary sources in classrooms with large numbers of ELL students (Akinyele, 2017; Patterson, Weaver, Fletcher, Connor, Thomas, \& Ross, 2018).Primary sources in U.S. history are often written in antiquated or professional types of English, which can be challenging for native English speakers, and even more so for those who are new to the language. Global history primary source excerpts often have the added disadvantage of being taken from outdated (free/public domain) English translations of historical texts, in order for textbook companies to keep their publishing costs down. Examples abound in various source books. The human record: Sources of global history(Andrea, 2001) includes excerpts from a multi-volume book published from 1879 to 1910 for selections titled "The classic of history," "The Upanishads," "The Bhagavad Gita," and "The book of good conduct" (pp. 26-28, 67-70, 70-74, 74-76, 495); excerpts from a 1913 translation for "Gathas" (pp. 85-88, 495); excerpts from an 1893 translation for "The analects" (pp. 99-102, 495-496); excerpts from an 1881 translation for "The history of the Peloponnesian War" (pp. 113-119, 496); and excerpts from an 1886 translation for "Travels in India and Ceylon" (pp. 164-169, 496). Aspects of Western civilization (Rogers, 2003) contains excerpts from a 1901 translation of Voltaire (pp. 66-69), while Readings in world history (2000) features an excerpt from a 1926 translation for "Beethoven's Heiligenstadt Testament" (pp. 167-169, 328). Meanwhile, Sources of the West (Kishlansky, 2003) includes excerpts from a 1915 translation for "The creation epic (ca. 2000 B.C.)" (pp. 6-11, 351), excerpts from an 1888 translation of Plato (pp. 57-65, 351), excerpts from an 1866 translation of Aristotle (pp. 66-69, 352), excerpts from a 1910 translation of Virgil (pp. 74-78, 352), excerpts from a 1908 translation of Plutarch (pp. 85-88, 352), and excerpts from a 1900 translation of the Magna Carta (pp. 174-177, 353). Finally, Discovering the global past (Wiesner, Wheeler, Doeringer, \&Curtis, 2002) features excerpts from a 1929 translation for "Usamah ibn-Munqidh describes the Franks" (pp. 191-193),and excerpts from a 1914 translation for a section titled "Book of description of countries, ca. 1320 s" (pp. 280-282).

Such excerpts can be difficult for students to relate to and understand, especially ELLs, and in many cases help develop impractical reading skills. For example, students are not likely to encounter the type of language used in many of these sources after completing school. On the other hand, students likely will encounter the type of writing used in news/media articles. This is certainly not to say that social studies teachers should abandon the incorporation of primary source materials. Indeed, a survey of social studies teachers in Western New York revealed that $82 \%$ ranked the examination of primary sources as the most valuable instructional practice (Serure, 2018). However, adopting news articles to develop critical thinking skills can supplement, or take the place of, some of social studies classes' traditional emphasis on historical primary source activities meant to promote literacy and critical thinking skills (Bunch, 2014; Segovia, 2017; Piazza, Rao, \& Protacio,2015).In an era of growing diversity and globalization, teachers across the U.S. are increasingly encouraged to develop culturally responsive instruction, learning about the cultural and linguistic characteristics of the students in their class and adapting instruction accordingly (Hess, 2008; Martins-Shannon \& White, 2012; Enright, 2012).Integrating news articles into history classes to teach both content and civic literacy skills has the potential to help develop culturally responsive instruction, to great benefit for social studies teachers with large ELL populations. Social studies teachers should always think purposefully about their instructional choices and their students' unique learning needs and backgrounds, to devise meaningful lessons that will support the development of students' cognitive learning skills to better prepare them for the future and develop a set of literacies that will enable them to think critically, communicate effectively, and ultimately act conscientiously.

\section{News Articles in Social Studies}

The use of news articles in social studies curricula is notnew in itself (Schmidt, 2007). Walter Parker has identified three general approaches to using news/current events in social studies: a) Teaching current events in addition to social studies, b) Using current events to supplement or reinforce the regular social studies content, and c) Using news/current events as a basis for teaching social studies content. As summarized in Table 1, there are benefits and drawbacks to each of these three broad approaches (Parker, 2012, pp. 206-212).

The first approach, which involves teaching current events in addition to the social studies curriculum, would include such activities as a homework assignment requiring each student to find an interesting news article and bring it to class and share. Other examples might include setting aside some portions of classroom instruction to use special news magazines developed for school use. Such magazines, including Scholastic News, Junior Scholastic, and Upfront (from The New York Times), all attempt to spark students' interest in the world and present articles written in a format targeted toward upper elementary or secondary students. Such as approach can create regularly scheduled time for news/current events, help build awareness of events, promote literacy skills, and offer a "break" from the regular social studies curriculum. 
However, it can also separate the news/current events from the main topics of the social studies classroom, potentially making these activities seem less relevant or significant in comparison to other work done in the class. The second approach is to use current events to supplement or reinforce the regular social studies content. Activities falling under this approach also include students (or the teacher) finding and bringing news to the class to share. This approach involvesan attempt to relate the news story to an area of history the class is studying, and draws parallels. The benefits of this approach include more explicit connections between the curriculum and the news/current events. The news story will be more focused on what students are learning, and it can generate greater interest in the curriculum and help clarify its contemporary relevance. However, as the news story must connect to the social studies content in some way, this approach inevitably places a restriction on the range of news stories that would be appropriate.

The final approach, using news/current events as a basis for teaching social studies content, involves teachercreated units based on news/current events (which can be used as a springboard for learning). Such units can be highly motivating, help bridge school learning with life outside school, and advance valuable knowledge about the world. However, the development of such units requires flexible unit planning, further restricts the range of appropriate news stories, and may pose difficulties in terms of covering all curriculum topics.

Civics and government courses conduce to the use of news articles, partly because of a logical connection of the curriculum to civic literacy. This preference, however, has been influenced by the association of "news" with "current events." This strong association has limited the use of civic literacy activities using news articles in the teaching of U.S. and global history content, since history content focuses on past events. However, social studies teachers can use current news articles in such categories as "archaeology" and even "scientific news" (which often covers news in both the natural and social sciences) to find articles that relate directly to past events and figures to help teach U.S. and global history topics. Such news articles can then be used through either the second or third approach outlined above.

\section{Developing the Activity}

The first step in developing a civic literacy activity using news articles to also support the teaching of U.S. and global history is to find appropriate news. It is often easier for the teacher (rather than the student or students) to find the news articles that will be used. Various websites, such as the following, include a suitable selection of news articles related to new archeological and social scientific discoveries:

https://www.archaeologica.org/NewsPage.htm

https://www.archaeology.org/news

https://www.independent.co.uk/topic/Archaeology

https://www.bbc.com/news/topics/c1038wnxyy0t/archaeology

https://www.foxnews.com/category/science/archaeology

https://www.livescience.com/topics/archaeology

https://www.sciencedaily.com/news/fossils_ruins/archaeology/

https://phys.org/science-news/archaeology-fossils/

https://www.nytimes.com/topic/subject/archaeology-and-anthropology

The second step, after finding a selection of potential news articles, is to select which one(s) to use. When choosing an article, the following are helpful considerations: a) What unit/content topics could the article help teach? b) How does the news topic help relate social studies content to the present? c) Why might the content of the news article be interesting to students? and d) Does the news article contain a debate/challenge to traditional interpretations of past events or include varying opinions/points of view? Articles should relate to the history content that will be taught, as well as present a way to connect the past to the present. The articles should also revolve around topicsof interest to secondary students. Finally, articles that include varying opinions/points of view and/or a debate/challenge to traditional interpretations of past events are particularly beneficial, because they can also be used to help demonstrate how the study of the past is dynamic rather than static. Below are some sample headlines of articles that could be used to help reinforce global history or U.S. history content to help provide a guide:

"Scientists find 3.3 million-year-old toddler, youngest human ancestor" (Associated Press,

September 31, 2006)

"Writing: An Egyptian invention?" (https://whyfiles.org/079writing/2.html, 1999)

"Tomb raiders lead to discovery; grave of noted [Egyptian] dentists secret for 4,200 years" (Sierra Millman, Associated Press, October 23, 2006)

"Introducing the boy king; for first time, King Tut unmasked for public" (Anna Johnson, Associated Press, November 5, 2007)

"Ancient grave found in Greece" (Associated Press, August 29, 2009)

"Phoenicians live on in DNA" (Associated Press, October 2008) 
"A riddle of Ancient Greece solved?" (Associated Press, October 29, 2005)

"Roman shipwreck yields treasure: Fish bones" (Daniel Woolls, Associated Press, November 2006)

"More crystal skulls deemed fakes" (Richard Ingham, AFP, July 9, 2008)

"Buddhism: Time-tested tranquility" (Steven Barr, March 31, 2005)

"Treasure hunter strikes gold; find sheds light on medieval England's Anglo-Saxon world" (Associated Press, September 25, 2009)

"Robin Hood's Sherwood Forest in need of a rescue; part of Britain's national identity, home to old oaks" (Kate Schuman, Associated Press, November 5, 2007)

"El Nino may have helped Magellan" (Randolph E. Schmid, Associated Press, May 19, 2008)

"Scientists say Copernicus' grave found" (Associated Press, November 2008)

"Hunt for lost Da Vinci painting to resume in Florence" (Ariel David, Associated Press, January 14, 2007)

"Scientists reconstruct Dante's face" (Marta Falconi, Associated Press, 2007)

"Granddaughter of last jailed witch [in the UK] seeks pardon" (Sue Leeman, Associated Press, January 2007)

"[American] Civil War led abolitionists to summer camping" (Kristen Domonell, Republican-American, June 17, 2009)

"Yale plays a role in legend of Geronimo's missing skull" (Sean Murphy, Associated Press, 2009)

"Capone hideout up for sale, site may have aided in bootlegging" (Associated Press, September 20, 2009)

\section{Developing Questions}

After selecting an article, the next step is to develop corresponding questions that will generate the types of discussions/learning that you want your students to have (Parker, 2012, pp. 342-347). Read the article and reflect on what you want students to know. Based on what you have identified as important, devise questions that can serve as bridges to get them to where you want them to go. Questions should typically include three levels of progressing complexity.

First-level questions should be focused on developing an understanding of the text. These are essentially "Who," "What," "When," and "Where" questions. For example, using three of the sample articles above ("Yale plays a role in legend of Geronimo's missing skull," "Writing: An Egyptian invention?" and "Robin Hood's Sherwood Forest in need of a rescue; part of Britain's national identity, home to old oaks") some first-level questions might be:

Where do historians say Geronimo's skull is buried?

When did writing begin in ancient Egypt?

When did writing begin in Mesopotamia?

Why would Robin Hood have a hard time hiding out in Sherwood today?

Looking at the graph, what are some of the actions used to preserve ancient oaks in Sherwood?

Second-level questions should focus on pinpointing the significance ("Why" questions) of the content and arguments made in the text, including the identification of points of view and evidence. Using the same sample articles, some second-level questions could be:

Who is Towana Spivey and what is her opinion on Geronimo's skull?

What evidence is there to support the theory that Geronimo's skull was stolen?

What evidence does David Miller provide to counter the theory that the skull was stolen?

Why does Guenter Dreyer claim that Egypt had the first form of writing?

According to Robert Englund, how is writing further developed in Mesopotamia in comparison to Egypt?

Does John Baines agree or disagree with Dreyer? Why?

What are Dreyer's responses to Baines' arguments?

Why does Austin Brady think Sherwood should be saved? Is his opinion biased? Explain.

What is the tone of the article toward Sherwood's preservation? Explain.

Finally, third-level questions should ask students to evaluate the different points of view or evidence presented in the text and determine their own positions. Using the same sample articles, some second-level questions could be:

Considering the evidence, do you think that Geronimo's skull was stolen? Explain how you arrived at this conclusion.

Where do you think "writing" first emerged, Egypt or Mesopotamia? Write a response stating your position, using at least three supporting details from the article.

Teachers can also ask students to make explicit connections between the content of the news article and the history content that they are studying. Questions to help students make these connections would revolve around either how the news article expands on the information in the course materials (such as a textbook) or link what is being studied to the present.

An essay or other extended constructed response based on such connections can be used to extend learning. If the news article is being used as a hook to launch a unit, teachers should provide students with questions or activities 
with the news article that will foster further inquiry-based learning, such as developing a list of what they would like to know about the past as a result of the news article, or a list of critical issues or debates about the past brought out in the article that require further research and learning.

The use of such activities using news articles to teach U.S. and global history content while teaching civic literacy skills can serve as scaffolded instruction for larger activities or projects (Ciullo \& Dimino, 2017).Different types of literacy-based civics projects can be used to develop further effective learning experiences that foster students' engagement with the community and the world around them (Rosario-Ramos, Johnson, \& Sawada, 2016; Abdulkarim, Ratmaningsih, \& Anggraini, 2018; Ramirez \& Jaffee, 2016).

Table 1 Approaches to Using News/Current Events in Social Studies (Parker, 2012)

\begin{tabular}{|c|c|c|c|}
\hline Approach & Examples & Benefits & Drawbacks \\
\hline $\begin{array}{c}\text { Teaching current } \\
\text { social studion }\end{array}$ & $\begin{array}{c}\text { Homework: Bring an } \\
\text { article to class to share; } \\
\text { Scholastic News, } \\
\text { Upfront }\end{array}$ & $\begin{array}{c}\text { Regularly scheduled } \\
\text { time for news/current } \\
\text { events; } \\
\text { Builds awareness; } \\
\text { promotes literacy skills; } \\
\text { "refreshing" break }\end{array}$ & $\begin{array}{c}\text { Separates news/current } \\
\text { events from the main } \\
\text { topics of the social } \\
\text { studies classroom }\end{array}$ \\
\hline $\begin{array}{c}\text { Using current events to } \\
\text { supplement or } \\
\text { reinforce the regular } \\
\text { social studies content }\end{array}$ & $\begin{array}{c}\text { Having students find } \\
\text { news/current events that } \\
\text { relate to the topics of } \\
\text { study; Teacher brings in } \\
\text { news/current events that } \\
\text { relate to the topics of }\end{array}$ & $\begin{array}{c}\text { More explicit } \\
\text { connections between } \\
\text { curriculum and } \\
\text { news/current events; } \\
\text { News more focused on } \\
\text { what students are } \\
\text { learning; Can generate } \\
\text { interest in curriculum } \\
\text { and clarify its }\end{array}$ & $\begin{array}{c}\text { Restricts the range of } \\
\text { news stories that are } \\
\text { appropriate }\end{array}$ \\
\\
$\begin{array}{c}\text { Using news/current } \\
\text { events as a basis for } \\
\text { teaching social studies } \\
\text { content }\end{array}$ & $\begin{array}{c}\text { Units based around } \\
\text { news/current events } \\
\text { (used as a springboard } \\
\text { for learning) }\end{array}$ & $\begin{array}{c}\text { Can be highly } \\
\text { motivating; Bridges } \\
\text { school learning with life } \\
\text { outside school; Builds } \\
\text { knowledge base about } \\
\text { the world, etc. }\end{array}$ & $\begin{array}{c}\text { Can require flexible unit } \\
\text { planning; Further } \\
\text { restricts the range of } \\
\text { appropriate news stories; } \\
\text { May be difficult to cover } \\
\text { all local curriculum } \\
\text { topics }\end{array}$ \\
\hline
\end{tabular}

\section{References}

Abdulkarim, A., Ratmaningsih, N., \&Anggraini, D. Noor. (2016). DevelopingCivicpedia as a civic education elearning media to improve students' information literacy. Journal of Social Studies Education Research, $9(3), 45-61$.

Akinyele, M. T. (2017). Balancing culturally responsive pedagogy and historicalliteracy in urban high school classrooms: Exploring the tensions. Paper presented at the Annual Meeting of the American Educational Research Association, San Antonio, TX.

Andrea, A. J.\&Overfield, J. H., eds. (2001). The human record: Sources of global history, volume I-To 1700. 4th ed. Boston: Houghton Mifflin.

Bunch, G. C. (2014). The language of ideas and the language of display: Reconceptualizing "academic language" in linguistically diverse classrooms. International Multilingual Research Journal, 8(1), 70-86.

Ciullo, S.\&Dimino, J. A. (2017). The strategic use of scaffolded instruction in social studies interventions for students with learning disabilities. Learning Disabilities Research \& Practice, 32(3), 155-165.

Enright, K. A. (2012). Making it matter: Relevant instruction for new mainstream students. Kappa DeltaPi Record, 48(2), 67-71.

Haager, D.\&Osipova, A. V. (2017). Enhancing academic instruction for adolescent English language learners with or at risk for learning disabilities. Insights into Learning Disabilities, 14(1), 7-26.

Hess, D. (2008). Democratic education to reduce the divide. Social Education, 72(7), 373-376.

Higgins, P. D. (2012). The effects of using a critical thinking graphic organizer to improve Connecticut academic performance test interdisciplinary writing assessment scores. Ed.D. Dissertation, Western Connecticut State University.

Hodgin, E.\&Kahne, J. (2018). Misinformation in the information age: What teachers can do to support students. Social Education, 82(4), 208-212. 
Johnson, M. J.\&Janisch, C. (1988). Connecting literacy with social studies content.Social Studies and the Young Learner, 10(4), 6-9.

Kenna, J. L. \& Russell, W. B. III.(2014). Implications of common core state standards on the social studies. Clearing House: A Journal of Educational Strategies, Issues and Ideas, 87(2), 75-82.

Kenna, J. L. \& Russell, W. B. III.(2015). Secondary social studies teachers' time commitment when addressing the common core state standards. Journal of Social Studies Education Research, 6(1), 26-48.

Kishlansky, M. A., eds. (2003). Sources of the West: Readings in Western civilization, Volume 1: From the beginning to 1715. New York: Longman.

Martins-Shannon, J. \& White, M. (2012). Support culturally responsive teaching! Kappa Delta Pi Record, 48(1), 46.

Marlatt, R. (2018). This is what we do: Emphasizing discipline-specific literacy practices in teacher education.Journal of Language and Literacy Education, 14(2) (Fall),2-23.

Middaugh, E. (2019). More than just facts: Promoting civic media literacy in the era of outrage.Peabody Journal of Education, 94(1), 17-31.

Mihailidis, P. (2018). Civic media literacies: Re-imagining engagement for civic intentionality learning. Media and Technology 43(2), 152-164.

Monte-Sano, C. (2011). Beyond reading comprehension and summary: Learning to read and write in history by focusing on evidence, perspective, and interpretation. Curriculum Inquiry, 41, 212-248.

New York State Education Department and the State University of New York. (2015). New York State Grades 912 Social Studies Framework. Retrieved from: http://www.nysed.gov/common/nysed/files/programs/curriculum-instruction/ss-framework-9-12.pdf

Paquette, K. R. \&Kaufman, C. C. (2008). Merging civic and literacy skills. Social Studies, 99(4), 187-192.

Parker, W. C. (2012). Social studies in elementary education. 14th ed. Boston: Pearson.

Partnership for 21st Century Skills (2019). Framework for 21st century learning. Retrieved from :http://www.p21.org/about-us/p21 framework

Patterson, N., Weaver, J., Fletcher, J., Connor, B., Thomas, A., \& Ross, C. (2018). Leveraging literacies through collaborative, source-based planning and teaching in social studies and language arts. Journal of Adolescent \& Adult Literacy, 61(5), 523-532.

Piazza, S. V., Rao, S., \&Protacio, M. S. (2015). Convergingrecommendations for culturally responsive literacy practices: students with learning disabilities, English language learners, and socioculturally diverse learners. International Journal of Multicultural Education, 17(3), 1-20.

Ramirez, P., \&Jaffe, A. T. (2016). Culturally responsive active citizenship education for newcomer students: A cross-state case study of two teachers in Arizona and New York. International Journal of Multicultural Education, 18(1), 45-67.

Readings in World History (2000). Austin, TX: Holt, Rinehart and Winston.

Rogers, P. M. (2003). Aspects of Western civilization, volume II: Problems and sources in history. 5th ed. Upper Saddle River, NJ: Pearson.

Rosario-Ramos, E. M., Johnson, L. R., \&Sawada, J. (2016). Literacy for citizenship: How youth participatory action research supports critical reflection on social issues. Paper presented at the Annual Meeting of the American Educational Research Association, Washington, DC.

Saint Onge, B., Scalia, S., \&Vega, L. F. (2008). Addressing adolescent literacy. District Administration, 44(1), 4651.

Schmidt, L. (2007). Social studies that sticks: How to bring content and concepts to life. Portsmouth, NH: Heinemann.

Schmoker, M. \&Jago, C. (2013). Simplifying the ELA Common Core; demystifying curriculum. KappaDelta Pi Record, 49(2), 59-63.

Segovia, M. (2017).Implementing the common core state standards for English language learners: Understanding how high school content teachers experience the instructional shifts. Ed.D. Dissertation, Northeastern University.

Serure, D. F. (2018). The current state of secondary social studies in Western New York. Ed.D. Dissertation, State University of New York at Buffalo.

Sharp, K. A.,\&Purdum, K. L. (2019). Revitalizing elementary social studies using informational texts. Paper presented at the Annual Conference of the Tennessee Council for the Social Studies, Gatlinburg, TN.

Shulsky, D. D., Baker, S. F., Chvala, T., \&Willis, J. M. (2017). Cultivating layered literacies: Developing the global child to become tomorrow's global citizen. International Journal of Development Education and Global Learning, 9(1), 49-63.

Spires, H. A.,Kerkhoff, S. N., Graham, A. C.K., Thompson, I., \&Lee, J. K. (2018). Operationalizing and validating disciplinary literacy in secondary education. Reading and Writing: An Interdisciplinary Journal, 31(6), 1401-1434. 
Stoll, M. R. (2018).Teachers' conceptualizations of writing and thinking in social studies. Ph.D. Dissertation, New York University.

Sweeney, M. A.\&Townsend, D. (2018). An analysis of discipline-specific academic language learning in middleschool students.Middle Grades Research Journal, 12(1), 9-21.

Waters, S.\&Watson, J. (2016). Examining the standardization of social studies content in the United States. Curriculum and Teaching, 31(1), 89-99.

Wiesner, M. E., Wheeler, W. B, Doeringer, F. M., \&Curtis, K. R. (2002).Discovering the global past: A look at the evidence, volume I-to 1600. 2nd ed. Boston: Houghton Mifflin. 